\title{
PENGARUH LINGKUNGAN TEMAN SEBAYA, KINERJA MENGAJAR GURU, DAN KEMANDIRIAN BELAJAR TERHADAP MOTIVASI BELAJAR DASAR-DASAR AKUNTANSI
}

\author{
THE EFFECT OF PEER ENVIRONMENT, TEACHER'S TEACHING \\ PERFORMANCE, AND LEARNING INDEPENDENCE TOWARD THE LEARNING \\ MOTIVATION IN STUDENTS OF FUNDAMENTAL OF ACCOUNTING
}

Oleh :

Nia Triansari

Prodi Pendidikan Akuntansi Universitas Negeri Yogyakarta

nia.trians@gmail.com

\section{Ani Widayati}

Staf Pengajar Jurusan Pendidikan Akuntansi Universitas Negeri Yogyakarta

\begin{abstract}
Abstrak
Penelitian ini bertujuan untuk mengetahui pengaruh Lingkungan Teman Sebaya, Kinerja Mengajar Guru, dan Kemandirian Belajar secara sendiri-sendiri atau bersama-sama terhadap Motivasi Belajar Dasar-dasar Akuntansi Siswa Kelas X Akuntansi SMK Negeri 1 Tempel Tahun Ajaran 2018/2019. Jenis penelitian adalah ex post facto dengan populasi sebanyak 96 siswa. Metode pengumpulan data menggunakan kuisioner. Validitas instrumen dibuktikan dengan rumus Korelasi Product Moment sedangkan reliabilitas diestimasi menggunakan rumus Alpha Cronbach. Uji prasyarat analisis data meliputi uji linearitas, uji multikolinearitas, dan uji heteroskedastisitas. Teknik analisis data menggunakan analisis regresi sederhana dan analisis regresi ganda. Hasil penelitian ini menunjukkan: 1)Terdapat pengaruh positif Lingkungan Teman Sebaya terhadap Motivasi Belajar Dasar-dasar Akuntansi ditunjukkan dengan nilai $\left.\mathrm{r}_{\mathrm{x} 1 \mathrm{y}}=0,490 ; \mathrm{r}_{\mathrm{x} 1 \mathrm{y}}=0,240 ; 2\right)$ Terdapat pengaruh positif Kinerja Mengajar Guru terhadap Motivasi Belajar Dasar-dasar Akuntansi ditunjukkan nilai $\mathrm{r}_{\mathrm{x} 2 \mathrm{y}}=0,369$; $\left.r_{x 2 y}^{2}=0,136 ; 3\right)$ Terdapat pengaruh positif Kemandirian Belajar terhadap Motivasi Belajar Dasar-dasar Akuntansi ditunjukkan dengan nilai $r_{x 3 y}=0,765 ; r_{x 3 y}^{2}=0,586$; dan 4)Terdapat pengaruh positif Lingkungan Teman Sebaya, Kinerja Mengajar Guru, dan Kemandirian Belajar secara bersama-sama terhadap Motivasi Belajar Dasar-dasar Akuntansi ditunjukkan dengan nilai $\mathrm{R}_{\mathrm{y}(123)}=0,786 ; \mathrm{R}_{\mathrm{y}(123)}^{2}=0,618$.
\end{abstract}

Kata kunci: Motivasi Belajar Dasar-dasar Akuntansi, Lingkungan Teman Sebaya, Kinerja Mengajar Guru, Kemandirian Belajar, SMK Negeri 1 Tempel

\begin{abstract}
This research aims to know the effect of Peer Environment, Teacher Teaching Performance, and Learning Independence joinly or individually toward the Learning Motivation in Students of Fundamental of Accounting Class X Accounting of SMK Negeri 1 Tempel Academic Year 2018/2019. This research is an ex post facto type with a population of 96 students. Method of data collection used questionnaires. Instruments validity was proven using Product Moment Correlation while reliability was estimated using Alpha Cronbach. Test of classical assumptions consisted of linearity test, multicollinearity test, and heteroscedasticity test. The data were analyzed by using simple regression analysis and multiple regression
\end{abstract}


analysis. The results of this research indicate: 1)There is a positive effect of Peer Environtment toward the Learning Motivation of Accounting Basics represented by $r_{x 1 y}=0,490 ; r_{x 1 y}^{2}=0,240$; 2)There is a positive effect of Teacher Teaching Performance toward the Learning Motivation of Accounting Basics represented by $\left.r_{x 2 y}=0,369 ; r_{x 2 y}^{2}=0,136 ; 3\right)$ There is a positive effect of Learning Independence toward the Learning Motivation of Accounting Basics represented by $r_{x 3 y}=0,765 r_{x 3 y}^{2}=0,586$; and 4)There is a positive effect of Peer Environtment, Teacher Teaching Performance, and Learning Independence joinly toward the Learning Motivation of Accounting Basics represented by $R_{y(123)}=0,786 ; R_{y(123)}^{2}=0,618$.

Keywords: Learning Motivation in Students of Fundamental of Accounting, Peer Environtment, Teacher Teaching Performance, Learning Independence, SMK Negeri 1 Tempel

\section{PENDAHULUAN}

Ilmu pengetahuan mengalami perkembangan yang semakin modern dan membutuhkan sumber daya manusia yang berkualitas tinggi. Peningkatan kualitas sumber daya manusia merupakan syarat untuk mencapai tujuan pembangunan nasional. Salah satu cara untuk meningkatkan kualitas sumber daya manusia tersebut adalah melalui pendidikan. Pendidikan merupakan suatu proses yang mendasar dalam kehidupan manusia yang akan berlangsung sepanjang hayat. Pendidikan merupakan suatu usaha yang dilakukan secara sengaja, sadar, dan terencana untuk mengubah perilaku individu, sebagaimana tercantum dalam UU Nomor 20 Tahun 2003 tentang Sistem Pendidikan Nasional:

Pendidikan adalah usaha sadar dan terencana untuk mewujudkan suasana belajar dan proses pembelajaran agar peserta didik secara aktif mengembangkan potensi dirinya untuk memiliki kekuatan spiritual keagamaan, pengendalian diri, kepribadian, kecerdasan, akhlak mulia, serta keterampilan yang diperlukan dirinya, masyarakat, bangsa dan negara.

Sugihartono (2013: 3) menjelaskan pendidikan sebagai "usaha yang dilakukan secara sadar dan sengaja untuk mengubah tingkah laku baik secara individu maupun kelompok untuk mendewasakan manusia melalui upaya pengajaran dan pelatihan". Pendidikan memiliki peran penting dalam pengembangan kemampuan manusia supaya dapat menghasilkan sumber daya manusia yang berkualitas. Peningkatan mutu pendidikan dikatakan berhasil jika kualitas pendidikan yang telah ditetapkan dapat tercapai dan berdampak pada meningkatnya kualitas sumber daya manusia. Salah satu cara yang dapat dilakukan untuk meningkatkan kualitas pendidikan adalah dengan melaksanakan proses pembelajaran secara efektif dan efisien agar motivasi belajar peserta didik dapat meningkat dan dapat mencapai prestasi belajar yang optimal. Oleh karena itu, dapat dikatakan bahwa pendidikan sangat berperan penting dalam penentuan kualitas generasi di suatu negara.

Dalam Peraturan Pemerintah No 17 Tahun 2010 tentang Pengelolaan dan Penyelenggaraan Pendidikan disebutkan pengertian Sekolah Menengah Kejuruan (SMK) sebagai berikut.

Sekolah Menengah Kejuruan (SMK) adalah salah satu bentuk satuan pendidikan formal yang menyelenggarakan pendidikan kejuruan pada jenjang Pendidikan Menengah sebagai lanjutan dari SMP, MTs, atau bentuk lain yang sederajat atau lanjutan dari hasil belajar yang diakui sama atau setara SMP atau MTs.

Sekolah Menengah Kejuruan (SMK) membekali siswa dengan pengetahuan dan keterampilan sesuai jurusan yang diambil. Yamin (2008: 77) mengemukakan tujuan dari Sekolah Menengah Kejuruan (SMK) adalah "untuk meningkatkan kecerdasan, pengetahuan, kepribadian, akhlak mulia, serta keterampilan peserta didik untuk hidup mandiri dan mengikuti pendidikan lebih 
lanjut sesuai dengan kejuruannya". Sekolah Menengah Kejuruan (SMK) mengutamakan pengembangan kemampuan siswa untuk melaksanakan jenis pekerjaan tertentu dan penyiapan siswa untuk memasuki lapangan kerja serta mengembangkan sikap profesional.

SMK Negeri 1 Tempel merupakan salah satu sekolah menengah kejuruan bidang bisnis dan manajemen di kabupaten Sleman yang menawarkan program keahlian Akuntansi. Sesuai dengan tujuan yang telah ditetapkan, program keahlian Akuntansi menuntut siswa untuk memahami konsep, teori, dan praktik serta mempunyai keterampilan dalam membuat laporan keuangan. Salah satu materi pelajaran program keahlian Akuntansi yang diajarkan pada siswa kelas X SMK Negeri 1 Tempel yaitu Dasar-dasar Akuntansi. Mata pelajaran Dasar-dasar Akuntansi merupakan materi pembelajaran kejuruan atau produktif. Dalam mata pelajaran ini, siswa mempelajari konsep dasar Akuntansi mulai dari pengertian, persamaan dasar, menganalisis transaksi, sampai dengan keterampilan membuat laporan keuangan. Apabila siswa ingin berhasil dalam mempelajari Akuntansi tersebut, tentunya dibutuhkan kemampuan dan motivasi belajar yang tinggi.

Motivasi memiliki kedudukan yang penting dalam mencapai tujuan pembelajaran yang telah ditetapkan. Motivasi atau dorongan dapat dikatakan sebagai serangkaian usaha untuk menyediakan kondisi-kondisi tertentu sehingga seseorang mau dan ingin melakukan sesuatu. Sardiman (2014: 75) menyatakan bahwa "motivasi belajar akan menimbulkan kegiatan belajar, menjamin kelangsungan kegiatan belajar, dan memberikan arah pada kegiatan belajar untuk mencapai tujuan yang ditetapkan". Munculnya motivasi tidak semata-mata dari diri siswa sendiri, tetapi guru harus melibatkan diri untuk memotivasi belajar siswa. Adanya motivasi akan memberikan semangat sehingga siswa akan mengetahui arah belajarnya sehingga tujuan pembelajaran yang sudah dirumuskan dapat tercapai secara optimal.

Motivasi belajar Dasar-dasar Akuntansi merupakan suatu dorongan yang berkaitan dengan keinginan siswa untuk mempelajari Akuntansi. Dorongan belajar ini dapat tercermin dari adanya aktivitas dan partisipasi siswa terhadap pembelajaran Dasar-dasar Akuntansi. Aktivitas dan partisipasi tersebut dapat berupa aktif dalam kegiatan pembelajaran, mempunyai rasa ingin tahu, berani menyampaikan pendapat, mampu memecahkan masalah yang dihadapi, dan teliti dalam mengerjakan soal. Selain itu, Motivasi Belajar Dasar-dasar Akuntansi ini dapat dipengaruhi oleh dua faktor yang meliputi faktor internal dan faktor eksternal. Motivasi yang tumbuh dari dalam diri siswa berupa minat belajar siswa terhadap pelajaran Akuntansi. Keadaan di luar diri siswa juga dapat merangsang tumbuhnya Motivasi Belajar siswa, diantaranya kondisi lingkungan belajar siswa, unsur-unsur dinamis dalam belajar, dan upaya guru dalam membelajarkan siswa melalui metode mengajar yang digunakan guru.

Pendidikan pada tingkat SMK tidak terlepas dari dunia remaja. Saat masa remaja interaksi pergaulan dengan teman sebaya menjadi meningkat. Teman sebaya merupakan orang terdekat dalam kehidupan siswa, sehingga perilaku dari teman sebaya dapat mempengaruhi motivasi belajar. Salah satu fungsi penting dari kelompok teman sebaya adalah untuk memberikan sumber informasi dan perbandingan tentang dunia di luar keluarga (Santrock, 2009: 111). Fungsi teman sebaya dalam hal belajar yakni dapat membantu dalam hal kesulitan belajar. Biasanya, bahasa yang digunakan teman sebaya lebih mudah dipahami, tidak ada rasa canggung untuk bertanya dan meminta bantuan ketika kesulitan atau tidak paham dalam belajar. Oleh karena itu, diharapkan siswa memiliki interaksi dengan teman sebaya yang positif dan baik sehingga dapat meningkatkan motivasi belajar mereka.

Untuk menciptakan kegiatan belajar yang kondusif dan menarik tidak terlepas dari 
peran pendidik dalam memberikan materi pelajaran. Kinerja mengajar guru berkaitan dengan kegiatan guru dalam proses pembelajaran, yaitu bagaimana seorang guru merencanakan kegiatan pembelajaran, melaksanakan kegiatan pembelajaran, dan menilai hasil belajar. Adapun ukuran dari kinerja menurut T.R. Mitchell (1989) dalam Rusman (2014: 50) yakni dapat dilihat dari quality of works, promthness, initiative, and communication. Pendidik dapat menggunakan metode mengajar dan media pembelajaran yang menarik dan bervariasi untuk menumbuhkan motivasi belajar siswa.

Selain faktor-faktor yang dijelaskan di atas, kemandirian belajar juga dapat mempengaruhi tingkat motivasi belajar siswa. Tirtarahardja (2005: 50) mengatakan kemandirian belajar sebagai "aktivitas belajar yang berlangsungnya lebih didorong oleh kemauan sendiri, pilihan sendiri, dan tanggung jawab sendiri dari pembelajar". Ciri-ciri kemandirian belajar dari siswa dapat dilihat dari kepercayaan siswa, sikap tanggung jawab terhadap keputusan yang diambil sendiri, sikap berani menghadapi permasalahan, dan kemampuan inisiatifnya. Adanya kemandirian belajar siswa yang tinggi diharapkan dapat meningkatkan motivasi belajar siswa itu sendiri.

Berdasarkan observasi terhadap proses pembelajaran yang dilakukan pada tanggal 5 November 2018 di kelas X Akuntansi 2 SMK Negeri 1 Tempel Tahun Ajaran 2018/2019, ditemukan masalah pada motivasi belajar siswa kelas X Akuntansi 2. Motivasi belajar yang rendah menyebabkan kurangnya aktivitas dan semangat dalam kegiatan belajar siswa selama proses pembelajaran. Kegiatan belajar yang kurang tersebut ditunjukkan dengan siswa masih terlihat berbicara dengan temannya saat guru sudah masuk dan memulai pembelajaran. Rendahnya aktivitas dalam belajar juga ditandai dengan rasa ingin tahu siswa yang kurang saat guru menyampaikan materi. Akibatnya siswa kurang antusias saat diberikan kesempatan untuk bertanya dan memberikan pendapat atau tanggapan, sehingga guru harus mengulangi pertanyaan untuk mendapat respon dari siswa.

Tinggi rendahnya motivasi belajar siswa dipengaruhi pula oleh keberadaan teman sebaya siswa kelas X Akuntansi 2 SMK Negeri 1 Tempel. Teman sebaya merupakan orang terdekat dalam diri siswa yang keberadaanya bisa teman sebaya di sekolah atau teman sebaya di rumah. Lingkungan teman sebaya yang kurang mendukung ditandai dengan siswa yang hanya ikut-ikutan temannya jika akan belajar dan saat mengerjakan tugas. Siswa yang duduk di barisan depan cenderung memperhatikan dan tenang dalam kegiatan pembelajaran karena teman sebangkunya melakukan hal yang sama, sedangkan siswa yang duduk di barisan belakang meja nomor 3-4 atau sekitar 50\% siswa kurang memperhatikan penjelasan guru dan ramai dengan teman sebangkunya. Selain itu, dukungan dari teman sebaya di rumah masih rendah, siswa lebih memilih bermain daripada meluangkan waktu untuk belajar bersama.

Motivasi belajar siswa kelas X Akuntansi 2 SMK Negeri 1 Tempel juga dipengaruhi oleh upaya dan kinerja mengajar guru di dalam kelas. Kinerja mengajar guru berkaitan dengan kegiatan perencanaan, pelaksanaan, dan evaluasi pembelajaran. Kinerja mengajar guru dalam hal ini ditunjukkan dengan penggunaan metode mengajar yang digunakan guru, yaitu ceramah dan pemberian tugas untuk mengerjakan soal. Guru memanfaatkan papan tulis sebagai media di dalam kelas dan belum memanfaatkan media lain yang bervariasi. Hal tersebut mengakibatkan siswa kurang termotivasi dalam memperhatikan pelajaran yang diberikan. Siswa cenderung bosan dan lebih memilih untuk melakukan aktivitas lain seperti mengobrol dengan teman sebangkunya dan karena belajar pada akhir jam pembelajaran menyebabkan siswa tidak fokus dengan pelajaran. Kurang adanya kegiatan pembelajaran yang bervariasi dan menarik seperti penghargaan kepada siswa yang aktif juga menyebabkan motivasi belajar siswa rendah. 
Motivasi Belajar yang rendah juga ditunjukkan pada kemandirian belajar yang kurang. Kemandirian belajar berkaitan dengan aktivitas belajar yang didorong oleh kemauan siswa sendiri. Siswa tidak berusaha memanfaatkan sumber belajar lain yang ada di perpustakaan untuk tambahan materi. Siswa yang mencari referensi lain untuk tambahan materi belajar hanya sekitar 10 orang atau $31,25 \%$ selebihnya cenderung mengandalkan materi yang hanya diberikan oleh guru untuk belajar. Hal tesebut menunjukkan adanya kemandirian dan tanggungjawab belajar yang masih kurang. Rendahnya kemandirian belajar siswa di dalam kelas ditunjukkan ketika mengerjakan tugas dari guru, sekitar $50 \%$ siswa masih melihat dan bertanya kepada temannya dan masih ragu untuk mengemukakan pendapatnya di dalam kelas. Selain itu, siswa cenderung menghabiskan waktunya untuk hal yang lain dan tidak memperhatikan kebutuhan akan belajar. Mereka tidak akan belajar pada malam harinya apabila tidak ada tugas atau ulangan. Kemandirian belajar siswa yang rendah ini menunjukkan tanggung jawab dan motivasi belajar siswa yang kurang baik.

Berdasarkan uraian yang telah dijelaskan di atas, Motivasi Belajar siswa kelas X Akuntansi SMK Negeri 1 Tempel dapat dipengaruhi oleh berbagai faktor, maka peneliti ingin mengetahui pengaruh dari Lingkungan Teman Sebaya, Kinerja Mengajar Guru, dan Kemandirian Belajar terhadap Motivasi Belajar Dasar-dasar Akuntansi siswa kelas X Akuntansi SMK Negeri 1 Tempel Tahun Ajaran 2018/2019.

\section{METODE PENELITIAN Jenis Penelitian}

Penelitian ini merupakan penelitian jenis ex post facto yaitu penelitian yang dilakukan untuk meneliti peristiwa yang sudah terjadi dan tidak ada perlakuan terhadap variabelnya. Pendekatan yang digunakan dalam penelitian ini adalah pendekatan kuantitatif.

\section{Waktu dan Tempat Penelitian}

Penelitian ini dilaksanakan di SMK Negeri 1 Tempel yang beralamatkan di Jalan Magelang KM. 17, Jlegongan, Margorejo, Tempel, Sleman, Yogyakarta. Waktu penelitian dilaksanakan pada bulan November 2018 - Februari 2019.

\section{Populasi Penelitian}

Populasi dalam penelitian ini adalah seluruh siswa kelas X Akuntansi SMK Negeri 1 Tempel Tahun Ajaran 2018/2019 yang terdiri dari tiga kelas dan berjumlah keseluruhan 96 siswa.

Data, Instrumen, dan Teknik Pengumpulan

a. Teknik Pengumpulan Data

Teknik pengkumpulan data yang digunakan dalam penelitian ini adalah dengan menggunakan angket (kuisioner). Angket merupakan teknik pengumpulan data yang dilakukan dengan cara memberi seperangkat pertanyaan atau pernyataan tertulis kepada responden untuk dijawabnya. (Sugiyono, 2015: 142). Angket digunakan untuk memperoleh data langsung dari responden mengenai variabel Lingkungan Teman Sebaya, Kinerja Mengajar Guru, Kemandirian Belajar, dan Motivasi Belajar Dasardasar Akuntansi.

b. Instrumen Penelitian

Instrumen penelitian menurut Sugiyono (2015: 148) adalah suatu alat yang digunakan mengukur fenomena alam maupun sosial yang diamati. Instrumen yang digunakan dalam penelitian ini berupa lembar angket untuk mengukur variabel Lingkungan Teman Sebaya, Kinerja Mengajar Guru, Kemandirian Belajar, dan Motivasi Belajar Dasar-dasar Akuntansi.

c. Teknik Analisis Data

Teknik analisis data yang digunakan dalam penelitian ini adalah analisis 
regresi sederhana dan analisis regresi ganda. Sebelum analisis regresi tersebut dilakukan, maka harus dilakukan uji prasyarat analisis yang meliputi uji linearitas, uji multikolinearitas, dan uji heteroskedastisitas.

\section{HASIL PENELITIAN DAN PEMBA-} HASAN

\section{Deskripsi Data}

a. Motivasi Belajar Dasar-dasar Akuntansi

Berdasarkan perhitungan analisis data variabel Motivasi Belajar Dasardasar Akuntansi (Y), maka dapat diperoleh skor tertinggi 84 dan skor terendah 41 , dengan nilai mean sebesar 67,81; median sebesar 67,00; modus sebesar 69,00; dan standar deviasi sebesar 7,45.

Tabel 1. Distribusi Frekuensi Data Motivasi Belajar Dasardasar Akuntansi

\begin{tabular}{|c|c|c|}
\hline No & Interval & Frekuensi \\
\hline 1 & $41-46$ & 1 \\
\hline 2 & $47-52$ & 1 \\
\hline 3 & $53-58$ & 6 \\
\hline 4 & $59-64$ & 23 \\
\hline 5 & $65-70$ & 33 \\
\hline 6 & $71-76$ & 19 \\
\hline 7 & $77-82$ & 11 \\
\hline 8 & $83-88$ & 2 \\
\hline \multicolumn{2}{|c|}{ Jumlah } & 96 \\
\hline
\end{tabular}

Berdasarkan tabel di atas, dapat digambarkan histogram sebagai berikut:

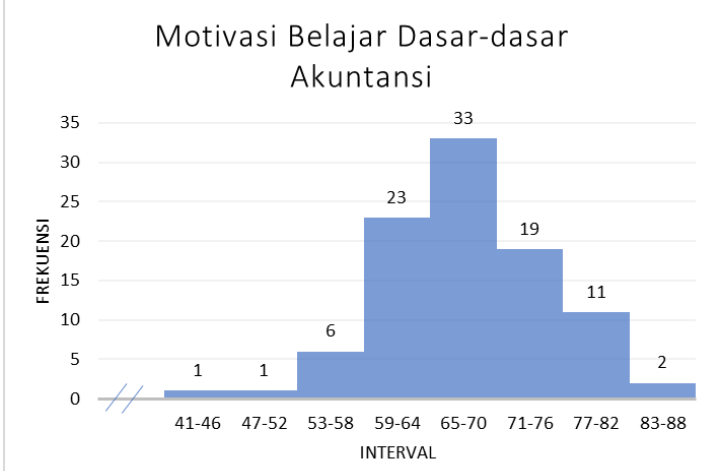

Gambar 1. Histogram Motivasi Belajar Dasar-dasar Akuntansi
Kategori kecenderungan variabel Motivasi Belajar Dasar-dasar Akuntansi (Y) dapat diperoleh kriteria sebagai berikut:

Tabel 2. Kategori Kecenderungan Motivasi Belajar Dasar-dasar Akuntansi

\begin{tabular}{|c|c|c|c|c|}
\hline No & Skor & Jumlah & $\%$ & Kategori \\
\hline 1 & $X \geq 69$ & 43 & $44,79 \%$ & $\begin{array}{c}\text { Sangat } \\
\text { tinggi }\end{array}$ \\
\hline 2 & $\begin{array}{l}57,5 \leq \\
X<69\end{array}$ & 49 & $51,04 \%$ & Tinggi \\
\hline 3 & $\begin{array}{c}46 \leq X \\
<57,5\end{array}$ & 3 & $3,13 \%$ & Rendah \\
\hline 4 & $X<46$ & 1 & $1,04 \%$ & $\begin{array}{l}\text { Sangat } \\
\text { rendah }\end{array}$ \\
\hline \multicolumn{2}{|c|}{ Total } & 96 & $100 \%$ & \\
\hline
\end{tabular}

Berdasarkan tabel di atas, dapat diketahui pada kategori sangat tinggi sebesar 44,79\% (43 responden), kategori tinggi sebesar $51,04 \%$ (49 responden), kategori rendah sebesar $3,13 \% \quad$ (3 responden), dan kategori sangat rendah sebesar 1,04\% (1responden). Dapat diambil kesimpulan bahwa kecenderungan Motivasi Dasar-dasar Akuntansi (Y) pada siswa kelas X Akuntansi SMK Negeri 1 Tempel adalah tinggi. Berikut merupakan pie chart kategori kecenderungan Motivasi Belajar Dasar-dasar Akuntansi (Y):

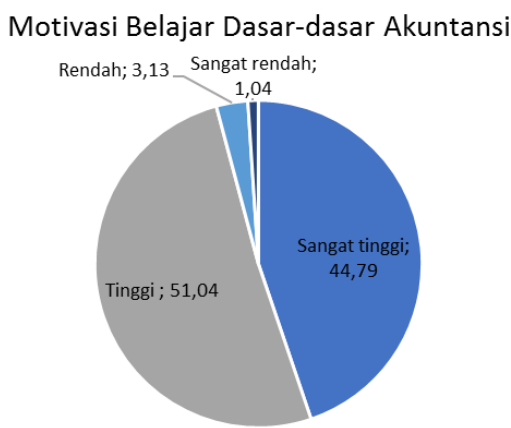

Gambar 2. Pie chart Motivasi Belajar Dasar-dasar Akuntansi 
b. Lingkungan Teman Sebaya

Berdasarkan perhitungan analisis data variabel Lingkungan Teman Sebaya (X1), maka dapat diperoleh skor tertinggi 72 dan skor terendah 43 , dengan nilai mean sebesar 54,65 ; median sebesar 54,00; modus sebesar 49,00; dan standar deviasi sebesar 5,79.

Tabel 3. Distribusi Frekuensi Data Lingkungan Teman Sebaya

\begin{tabular}{|c|c|c|}
\hline No & Interval & Frekuensi \\
\hline 1 & $43-46$ & 5 \\
\hline 2 & $47-50$ & 20 \\
\hline 3 & $51-54$ & 26 \\
\hline 4 & $55-58$ & 19 \\
\hline 5 & $59-62$ & 16 \\
\hline 6 & $63-66$ & 8 \\
\hline 7 & $67-70$ & 1 \\
\hline 8 & $71-74$ & 1 \\
\hline \multicolumn{2}{|c|}{ Jumlah } & 96 \\
\hline
\end{tabular}

Berdasarkan tabel di atas, dapat digambarkan sebagai berikut:

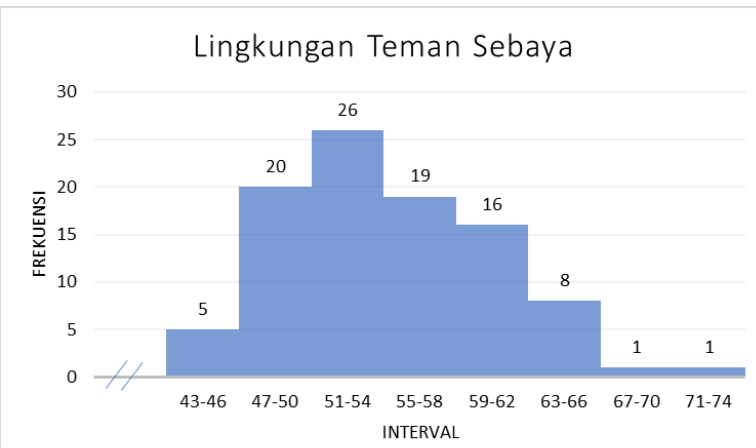

Gambar 3. Histogram Lingkungan Teman Sebaya

Kategori kecenderungan variabel Lingkungan Teman Sebaya (X1) dapat diperoleh kriteria sebagai berikut:

Tabel 4. Kategori Kecenderungan Lingkungan Teman Sebaya

\begin{tabular}{|c|c|c|c|c|}
\hline No & Skor & Frekuensi & $\%$ & Kategori \\
\hline 1 & $\begin{array}{c}\mathrm{X} \geq \\
57\end{array}$ & 32 & $33,33 \%$ & $\begin{array}{c}\text { Sangat } \\
\text { baik }\end{array}$ \\
\hline 2 & $\begin{array}{c}47,5 \\
\leq \mathrm{X} \\
<57\end{array}$ & 53 & $55,21 \%$ & Baik \\
\hline
\end{tabular}

\begin{tabular}{|c|c|c|c|c|}
\hline 3 & $\begin{array}{c}38 \leq \\
\mathrm{X}< \\
47,5\end{array}$ & 11 & $11,46 \%$ & $\begin{array}{c}\text { Kurang } \\
\text { baik }\end{array}$ \\
\hline 4 & $\begin{array}{c}\mathrm{X}< \\
38\end{array}$ & 0 & $0 \%$ & $\begin{array}{c}\text { Tidak } \\
\text { baik }\end{array}$ \\
\hline \multicolumn{2}{|c|}{ Total } & 96 & $100 \%$ & \\
\hline
\end{tabular}

Berdasarkan tabel di atas, dapat diketahui pada kategori sangat baik sebesar 33,33\% (32 responden), kategori baik sebesar $55,21 \%$ (53 responden), kategori kurang baik sebesar 11,46\% (11 responden), dan kategori tidak baik sebesar 0\% (0 responden). Dapat diambil kesimpulan bahwa kecenderungan Lingkungan Teman Sebaya (X1) pada siswa kelas X Akuntansi SMK Negeri 1 Tempel adalah baik. Berikut merupakan pie chart kategori Lingkungan Teman Sebaya (X1):

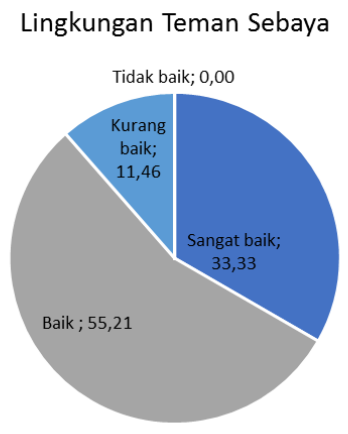

Gambar 4. Pie chart Lingkungan Teman Sebaya

c. Kinerja Mengajar Guru

Berdasarkan perhitungan analisis data variabel Kinerja Mengajar Guru (X2), maka dapat diperoleh skor tertinggi 75 dan skor terendah 47 , dengan nilai mean sebesar 61,03; median sebesar 61,00; modus sebesar 49,00; dan standar deviasi sebesar 5,89.

Tabel 5. Distribusi Frekuensi Data Kinerja Mengajar Guru

\begin{tabular}{|c|c|c|}
\hline No & Interval & Frekuensi \\
\hline 1 & $47-50$ & 1 \\
\hline 2 & $51-54$ & 14 \\
\hline 3 & $55-58$ & 19 \\
\hline 4 & $59-62$ & 20 \\
\hline
\end{tabular}




\begin{tabular}{|c|c|c|}
\hline 5 & $63-66$ & 22 \\
\hline 6 & $67-70$ & 14 \\
\hline 7 & $71-74$ & 5 \\
\hline 8 & $75-78$ & 1 \\
\hline \multicolumn{2}{|c|}{ Jumlah } & 96 \\
\hline
\end{tabular}

Berdasarkan tabel di atas, dapat digambarkan histogram sebagai berikut:

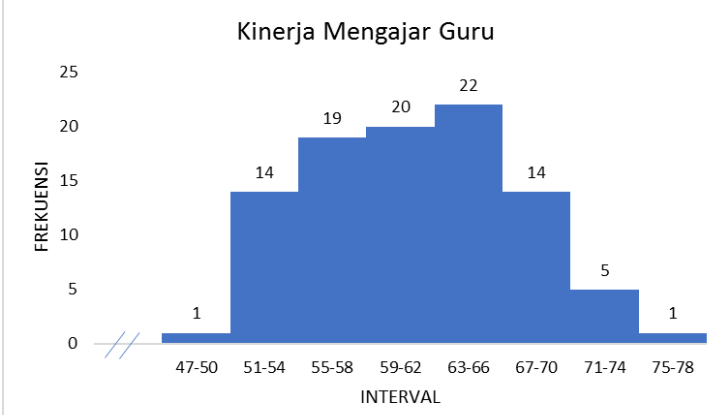

Gambar 5. Histogram Kinerja Mengajar Guru

Kategori kecenderungan variabel Kinerja Mengajar Guru (X2) dapat diperoleh kriteria sebagai berikut:

Tabel 6. Kategori Kecenderungan Kinerja Mengajar Guru

\begin{tabular}{|c|c|c|c|c|}
\hline No & Skor & Frekuensi & $\%$ & Kategori \\
\hline 1 & $\begin{array}{c}X \geq \\
60\end{array}$ & 57 & 59,38 & $\begin{array}{c}\text { Sangat } \\
\text { tinggi }\end{array}$ \\
\hline 2 & $\begin{array}{c}50 \leq \\
X< \\
60\end{array}$ & 38 & 39,58 & Tinggi \\
\hline 3 & $\begin{array}{c}40 \leq \\
X< \\
50\end{array}$ & 1 & 1,04 & Rendah \\
\hline 4 & $\begin{array}{c}X< \\
40 \\
\end{array}$ & 0 & 0 & $\begin{array}{l}\text { Sangat } \\
\text { rendah }\end{array}$ \\
\hline \multicolumn{2}{|c|}{ Total } & 96 & 100 & \\
\hline
\end{tabular}

Berdasarkan tabel di atas, dapat diketahui pada kategori sangat tinggi sebesar 59,38\% (57 responden), kategori tinggi sebesar $39,58 \%$ (38 responden), kategori rendah sebesar $1,04 \% \quad(1$ responden), dan kategori sangat rendah sebesar 0\% (0 responden). Dapat diambil kesimpulan bahwa kecenderungan Kinerja Mengajar Guru (X2) pada siswa kelas X Akuntansi SMK Negeri 1 Tempel adalah sangat tinggi. Berikut merupakan pie chart kategori kecenderungan Kinerja Mengajar Guru (X2):

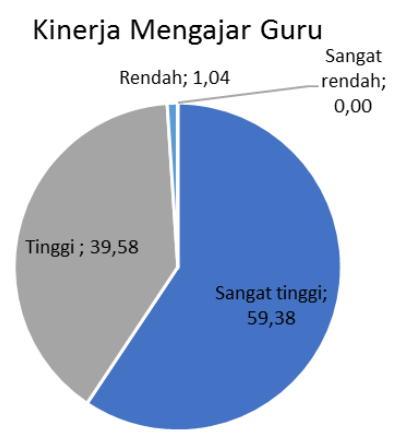

\section{Gambar 6. Pie chart Kinerja Mengajar Guru}

d. Kemandirian Belajar

Berdasarkan perhitungan analisis data variabel Kemandirian Belajar (X3), maka dapat diperoleh skor tertinggi 70 dan skor terendah 39, dengan nilai mean sebesar 54,20; median sebesar 54,00; modus sebesar 51,00; dan standar deviasi sebesar 6,63.

Tabel 7. Distribusi Frekuensi Data Kemandirian Belajar

\begin{tabular}{|c|c|c|}
\hline No & Interval & Frekuensi \\
\hline 1 & $39-42$ & 1 \\
\hline 2 & $43-46$ & 11 \\
\hline 3 & $47-50$ & 16 \\
\hline 4 & $51-54$ & 23 \\
\hline 5 & $55-58$ & 19 \\
\hline 6 & $59-62$ & 14 \\
\hline 7 & $63-66$ & 9 \\
\hline 8 & $67-70$ & 3 \\
\hline \multicolumn{2}{|c|}{ Jumlah } & 96 \\
\hline
\end{tabular}

Berdasarkan tabel di atas, dapat digambarkan histogram sebagai berikut: 


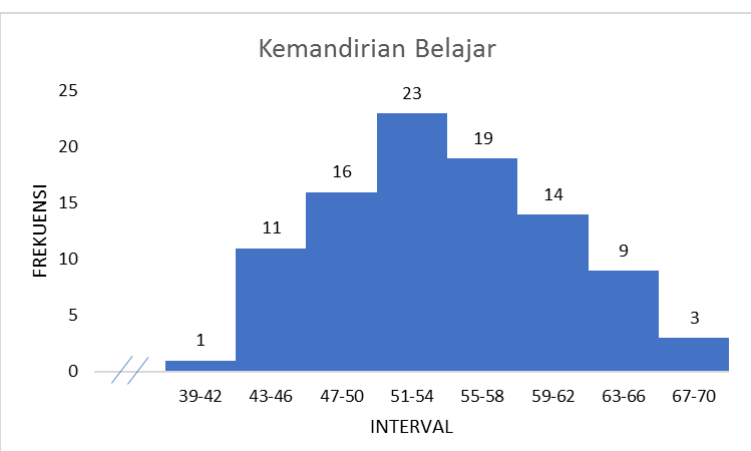

Gambar 7. Histogram Kemandirian Belajar

Kategori kecenderungan variabel Kemandirian Belajar (X3) dapat diperoleh kriteria sebagai berikut:

Tabel 8. Kategori Kecenderungan Kemandirian Belajar

\begin{tabular}{|c|c|c|c|c|}
\hline No & Skor & Frekuensi & $\%$ & Kategori \\
\hline 1 & $\begin{array}{c}X \geq \\
57\end{array}$ & 37 & 38,54 & $\begin{array}{c}\text { Sangat } \\
\text { tinggi }\end{array}$ \\
\hline 2 & $\begin{array}{l}47,5 \\
\leq X \\
<57\end{array}$ & 44 & 45,83 & Tinggi \\
\hline 3 & $\begin{array}{l}38 \leq \\
X< \\
47,5\end{array}$ & 15 & 15,63 & Rendah \\
\hline 4 & $\begin{array}{c}\mathrm{X}< \\
38\end{array}$ & 0 & 0 & $\begin{array}{l}\text { Sangat } \\
\text { rendah }\end{array}$ \\
\hline \multicolumn{2}{|c|}{ Total } & 96 & 100 & \\
\hline
\end{tabular}

Berdasarkan tabel di atas, dapat diketahui pada kategori sangat tinggi sebesar 38,54\% (37 responden), kategori tinggi sebesar $45,83 \%$ (44 responden), kategori rendah sebesar $15,63 \% \quad(15$ responden), dan kategori sangat rendah sebesar 0\% (0 responden). Dapat diambil kesimpulan bahwa kecenderungan Kemandirian Belajar (X3) pada siswa kelas X Akuntansi SMK Negeri 1 Tempel adalah tinggi. Berikut merupakan pie chart kategori kecenderungan Kemandirian Belajar (X3):

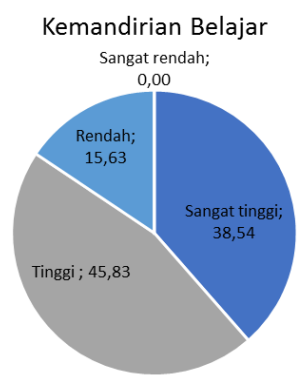

Gambar 8. Pie chart Kemandirian Belajar

\section{Uji Prasyarat Analisis}

a. Uji Linearitas

Uji linieritas dilakukan untuk mengetahui ada atau tidaknya hubungan secara langsung antara variabel bebas (X) dengan variabel terikat (Y) serta untuk mengetahui ada atau tidak perubahan pada variabel $\mathrm{X}$ diikuti dengan perubahan variabel Y. Hubungan variabel dapat dikatakan linear jika nilai Sig. lebih dari atau sama dengan 0,05. Uji liniearitas juga dapat menggunakan Uji $F$, jika $F_{\text {hitung }}$ lebih kecil atau sama dengan $F_{\text {tabel }}$ berarti hubungan kriterium dengan prediktor adalah linear dan jika $F_{\text {hitung }}$ lebih besar dari $F_{\text {tabel }}$ berarti hubungan kriterium dengan prediktor tidak linier dengan taraf signifikansi 5\%. Setelah dilakukan perhitungan, ringkasan hasil uji linearitas dapat dilihat sebagai berikut:

Tabel 9 . Hasil Uji Linearitas

\begin{tabular}{|c|c|c|c|c|}
\hline Variabel & Fhitung & Ftabel & Sig & Ket. \\
\hline X1 - Y & 1,169 & 1,682 & 0,301 & Linear \\
\hline X2 - Y & 1,257 & 1,702 & 0,234 & Linear \\
\hline X3 - Y & 1,579 & 1,666 & 0,070 & Linear \\
\hline
\end{tabular}

Sumber: Data primer yang sudah diolah

Berdasarkan tabel di atas, Fhitung pada masing-masing variabel lebih kecil dari $\mathrm{F}_{\text {tabel }}$ dengan taraf signifikansi $5 \%$. Hal ini berlaku untuk semua variabel bebas terhadap variabel terikat, sehingga dapat diambil kesimpulan bahwa semua variabel bebas memiliki hubungan yang linier terhadap variabel terikat. 
b. Uji Multikolinearitas

Uji multikolinearitas digunakan untuk mengetahui terjadi tidaknya multikoliniearitas antara variabel bebas yang satu dengan variabel bebas yang lain. Uji multikolinearitas dapat diketahui Jika koefisien korelasi antara variabel bebas lebih kecil atau sama dengan 0,600, maka tidak terjadi multikoliniearitas antara variabel bebas sehingga uji regresi dapat dilanjutkan. Setelah dilakukan perhitungan, ringkasan hasil uji multikolinearitas dapat dilihat sebagai berikut:

Tabel 10. Hasil Uji Multikolinearitas

\begin{tabular}{|c|c|c|c|c|}
\hline Variabel & X1 & $\mathrm{X} 2$ & $\mathbf{X 3}$ & Ket. \\
\hline X1 & 1 & 0,487 & 0,464 & \multirow{3}{*}{$\begin{array}{l}\text { Tidak terjadi } \\
\text { multikolinearitas }\end{array}$} \\
\hline $\mathrm{X} 2$ & 0,487 & 1 & 0,298 & \\
\hline X3 & 0,464 & 0,298 & 1 & \\
\hline
\end{tabular}

Sumber: Data primer yang sudah diolah

Berdasarkan tabel di atas, ketiga variabel bebas mempunyai nilai korelasi yaitu sebesar <0,600 maka dapat disimpulkan bahwa antar variabel bebas tidak terjadi multikolinearitas.

c. Uji Heteroskedastisitas

Uji heteroskedastisitas ini digunakan untuk menilai apakah ada ketidaksamaan varian dari residual untuk semua pengamatan pada model regresi linear. Syarat untuk melanjutkan ke analisis regresi harus dipenuhi syarat tidak adanya heteroskedastisitas, yaitu jika nilai Sig. < 0,05, maka menunjukkan terjadinya heteroskedastisitas. Sebaliknya, jika nilai Sig. > 0,05 maka tidak terjadi heteroskedastisitas. Setelah dilakukan perhitungan, ringkasan hasil uji heteroskedastisitas dapat dilihat sebagai berikut:

Tabel 11.Hasil Uji Heteroskedastisitas

\begin{tabular}{|c|c|c|}
\hline \multicolumn{3}{|c|}{ ANOVA } \\
\hline Model & F & Sig. \\
\hline Regression & 1,828 & 0,147 \\
\hline
\end{tabular}

\begin{tabular}{|c|c|c|}
\hline Variabel & Sig. & Keterangan \\
\hline X1 & 0,858 & Tidak terjadi \\
\cline { 1 - 2 } X2 & 0,174 & heteroskedastisitas \\
\hline X3 & 0,053 & \\
\hline
\end{tabular}

Sumber: Data primer yang sudah diolah
Berdasarkan tabel di atas, nilai $\mathrm{F}$ sebesar 1,828 dengan Sig. 0,147 dan nilai Sig. dari ketiga variabel bebas lebih besar dari 0,05, maka dapat disimpulkan bahwa antar variabel bebas tidak terjadi heteroskedastisitas.

\section{Pengujian Hipotesis}

a. Hipotesis Pertama

Hipotesis pertama yang diuji dalam penelitian ini adalah Lingkungan Teman Sebaya berpengaruh positif terhadap Motivasi Belajar Dasar-dasar Akuntansi Siswa Kelas X Akuntansi SMK Negeri 1 Tempel Tahun Ajaran 2018/2019.

Tabel 12. Hasil analisis regresi sederhana

\begin{tabular}{|c|c|c|c|c|}
\hline Model & Koef. & $\mathbf{r}_{\mathbf{1} 1 \mathbf{y}}$ & $\mathbf{r}^{\mathbf{2}} \mathbf{x 1 y}$ & Sig. \\
\hline (Konstanta) & 33,378 & 0,490 & 0,240 & 0,000 \\
X1 & 0,630 & & & \\
\hline
\end{tabular}

Sumber: Data primer yang sudah diolah

b. Hipotesis Kedua

Hipotesis kedua yang diuji dalam penelitian ini adalah Kinerja Mengajar Guru berpengaruh positif terhadap Motivasi Belajar Dasar-dasar Akuntansi Siswa Kelas X Akuntansi SMK Negeri 1 Tempel Tahun Ajaran 2018/2019. 
Tabel 13. Hasil analisis regresi sederhana $\left(\mathrm{X}_{2}-\mathbf{Y}\right)$

\begin{tabular}{|c|c|c|c|c|}
\hline Model & Koef. & $\mathbf{r}_{\mathbf{x} 1 \mathbf{y}}$ & $\mathbf{r}^{\mathbf{2}} \mathbf{x 1 y}$ & Sig. \\
\hline $\begin{array}{c}\text { (Konstanta) } \\
\text { X2 }\end{array}$ & $\begin{array}{c}39,294 \\
0,467\end{array}$ & 0,369 & 0,136 & 0,000 \\
\hline
\end{tabular}

Sumber: Data primer yang sudah diolah

c. Hipotesis Ketiga

Hipotesis ketiga yang diuji dalam penelitian ini adalah Kemandirian Belajar berpengaruh positif terhadap Motivasi Belajar Dasar-dasar Akuntansi Siswa Kelas X Akuntansi SMK Negeri 1 Tempel Tahun Ajaran 2018/2019.
Tabel 14. Hasil analisis regresi sederhana $\left(\mathbf{X}_{3}-\mathbf{Y}\right)$

\begin{tabular}{|c|c|c|c|c|}
\hline Model & Koef. & $r_{x 1 y}$ & $r_{x 1 y}^{2}$ & Sig. \\
\hline $\begin{array}{c}\text { (Konstanta) } \\
\text { X3 }\end{array}$ & $\begin{array}{c}21,237 \\
0,859\end{array}$ & 0,765 & 0,586 & 0,000 \\
\hline
\end{tabular}

Sumber: Data primer yang sudah diolah

d. Hipotesis Keempat

Hipotesis keempat yang diuji dalam penelitian ini adalah Lingkungan Teman Sebaya, Kinerja Mengajar Guru, dan Kemandirian Belajar secara bersama-sama berpengaruh positif terhadap Motivasi Belajar Dasar-dasar Akuntansi Siswa Kelas X Akuntansi SMK Negeri 1 Tempel Tahun Ajaran 2018/2019.

Tabel 15. Hasil analisis regresi ganda $\left(X_{1}, X_{2}, X_{3}-Y\right)$

\begin{tabular}{|c|c|c|c|c|c|}
\hline Model & Koef. & $\mathbf{r}_{\mathbf{y}}(\mathbf{1 2 3})$ & $\mathbf{r}_{\mathbf{y}}^{\mathbf{2}(\mathbf{1 2 3})}$ & Fhitung & Sig. \\
\hline Konstanta & 9,648 & & & & \\
X1 & 0,160 & 0,786 & 0,618 & 49,539 & 0,000 \\
X2 & 0,136 & & & & \\
X3 & 0,758 & & & \\
\hline
\end{tabular}

Sumber: Data primer yang sudah diolah

Tabel 16. Sumbangan Relatif dan Sumbangan Efektif

\begin{tabular}{|c|c|c|}
\hline $\begin{array}{c}\text { Nama Variabel } \\
\text { Bebas }\end{array}$ & SR & SE \\
\hline $\begin{array}{c}\text { Lingkungan Teman } \\
\text { Sebaya }\end{array}$ & $15 \%$ & $9,3 \%$ \\
\hline $\begin{array}{c}\text { Kinerja Mengajar } \\
\text { Guru }\end{array}$ & $14,2 \%$ & $8,8 \%$ \\
\hline Kemandirian Belajar & $70,8 \%$ & $43,7 \%$ \\
\hline TOTAL & $100 \%$ & $61,8 \%$ \\
\hline
\end{tabular}

Sumber: Data primer yang sudah diolah

Berdasarkan tabel di atas, dapat diketahui bahwa Lingkungan Teman Sebaya memberikan sumbangan relatif sebesar $15 \%$, Kinerja Mengajar Guru memberikan sumbangan relatif sebesar 14,2\%, dan Kemandirian Belajar memberikan sumbangan relatif sebesar 70,8\%. Sumbangan efektif yang diberikan oleh variabel Lingkungan Teman Sebaya sebesar 9,3\%, Kinerja Mengajar Guru memberikan sumbangan efektif sebesar 8,8\%, dan Kemandirian Belajar memberikan sumbangan efektif sebesar $43,7 \%$. Total sumbangan efektif sebesar $61,8 \%$ yang berarti Lingkungan Teman Sebaya, Kinerja Mengajar Guru, dan Kemandirian Belajar secara bersama-sama memberikan sumbangan efektif sebesar $61,8 \%$ terhadap Motivasi Belajar Dasar-dasar Akuntansi sedangkan $38,2 \%$ dari variabel lain yang tidak diteliti dalam penelitian ini.

\section{Pembahasan}

1. Pengaruh Lingkungan Teman Sebaya terhadap Motivasi Belajar Dasardasar Akuntansi

Berdasarkan hasil analisis regresi sederhana, diperoleh koefisien korelasi $r_{x 1 y}$ sebesar 0,490 yang bernilai positif berarti Lingkungan Teman Sebaya memilki pengaruh positif terhadap Motivasi Belajar 
Dasar-dasar Akuntansi. Harga koefisien determinasi $\mathrm{r}^{2}{ }_{\mathrm{x} 1 \mathrm{y}}$ sebesar 0,240 yang menunjukkan bahwa Lingkungan Teman Sebaya memiliki kontribusi pengaruh terhadap Motivasi Belajar Dasar-dasar Akuntansi Siswa Kelas X Akuntansi SMK Negeri 1 Tempel Tahun Ajaran 2018/2019 sebesar 24\% sedangkan $76 \%$ ditentukan oleh variabel lain yang tidak diteliti dalam penelitian.

Hasil penelitian ini diperkuat dengan penelitian yang dilakukan oleh Puji Lestari (2017) yang berjudul "Pengaruh Aspirasi Siswa, Lingkungan Teman Sebaya, dan Pemanfaatan Sumber Belajar terhadap Motivasi Belajar Akuntansi Perusahaan Jasa Siswa Kelas X Akuntansi SMK Negeri 2 Purworejo Tahun Ajaran 2016/2017”. Hasil penelitian menunjukkan terdapat pengaruh positif Lingkungan Teman Sebaya terhadap Motivasi Belajar Akuntansi Perusahaan Jasa dengan $\mathrm{Y}=0,746 \mathrm{X} 2+22,711 ; \quad$ koefisien korelasi $\left(\mathrm{r}_{\mathrm{x} 2 \mathrm{y}}\right)$ sebesar 0,653; dan koefisien determinasi $\left(r^{2} \times 2 y\right)$ sebesar 0,427 . Lingkungan Teman Sebaya memberikan sumbangan relatif sebesar $50,53 \%$ dan sumbangan efektif sebesar $29,11 \%$.

Hasil penelitian ini didukung oleh pendapat Dimyati dan Mudjiono (2009) bahwa motivasi belajar dipengaruhi oleh beberapa faktor yang salah satunya adalah kondisi lingkungan siswa. Lingkungan siswa ini tidak terlepas dari lingkungan teman sebaya. Hal tersebut juga didukung oleh Eveline Siregar dan Hartini Nara (2014:53-55) yang menyebutkan bahwa kondisi lingkungan siswa yang terdiri dari lingkungan fisik dan lingkungan sosial memiliki pengaruh dalam meningkatkan motivasi belajar siswa. Hal ini bisa dilihat ketika siswa belajar pada kondisi lingkungan fisik yang baik dan kondusif maka akan memberikan pengaruh positif seperti merasa nyaman untuk belajar. Rasa nyaman itu akan meningkatkan motivasi siswa dalam belajar. Lingkungan sosial yang menunjukkan kebiasaan belajar juga akan berpengaruh terhadap motivasi belajar. Dengan demikian dapat disimpulkan bahwa semakin baik kondisi Lingkungan Teman Sebaya maka akan semakin baik pengaruhnya terhadap peningkatan Motivasi Belajar Dasar-dasar Akuntansi.

2. Pengaruh Kinerja Mengajar Guru terhadap Motivasi Belajar Dasardasar Akuntansi

Berdasarkan hasil analisis regresi sederhana, diperoleh koefisien korelasi $r_{x 2 y}$ sebesar 0,369 yang bernilai positif berarti Kinerja Mengajar Guru memilki pengaruh positif terhadap Motivasi Belajar Dasar-dasar Akuntansi. Harga koefisien determinasi $r_{x 2 y}^{2}$ sebesar 0,136 yang menunjukkan bahwa Kinerja Mengajar Guru memiliki kontribusi pengaruh terhadap Motivasi Belajar Dasar-dasar Akuntansi Siswa Kelas X Akuntansi SMK Negeri 1 Tempel Tahun Ajaran 2018/2019 sebesar 13,6\% sedangkan $86,4 \%$ ditentukan oleh variabel lain yang tidak diteliti dalam penelitian.

Hasil penelitian ini diperkuat dengan penelitian yang dilakukan oleh Palupi Angun Kumalasari (2016) yang berjudul "Pengaruh Pemanfaatan Sumber Belajar dan Persepsi Siswa tentang Metode Mengajar Guru terhadap Motivasi Belajar Akuntansi Siswa Kelas XI Akuntansi SMK Negeri 1 Tempel Tahun Ajaran 2015/2016". Hasil penelitian menunjukkan bahwa terdapat pengaruh positif Persepsi 
Siswa tentang Metode Mengajar Guru terhadap Motivasi Belajar Akuntansi siswa kelas XI Akuntansi SMK Negeri 1 Tempel Tahun Ajaran 2015/2016 dengan $\mathrm{Y}=0,525 \mathrm{X}_{2}+$ 17,48; koefisien korelasi $\mathrm{r}_{\mathrm{x} 2 \mathrm{y}}$ sebesar 0,529 ; dan koefisien determinasi $\mathrm{r}^{2} \mathrm{x} 2 \mathrm{y}$ sebesar 0,28. Persepsi Siswa tentang Metode Mengajar Guru memberikan sumbangan relatif sebesar $51,11 \%$ dan sumbangan efektif sebesar $42,28 \%$.

Selain itu hasil penelitian juga selaras dengan penelitian yang dilakukan oleh Titis Haryo Mukti (2016) yang berjudul "Pengaruh Persepsi Siswa tentang Metode Mengajar Guru dan Media Pembelajaran terhadap Motivasi Belajar pada Kompetensi Kejuruan Akutansi Kelas XI SMK YPKK 1 Sleman Tahun Ajaran 2015/2016". Hasil penelitian menujukkan terdapat pengaruh positif Persepsi Siswa tentang Metode Mengajar Guru terhadap Motivasi Belajar Akuntansi Siswa Kelas XI Akuntansi SMK YPKK 1 Sleman Tahun Ajaran 2015/2016, dengan $\mathrm{rx}_{1} \mathrm{y}=0,497$; $\mathrm{r}^{2} \mathrm{x}_{1} \mathrm{y}=0,247$; konstanta $=23,260$, dan koefisien $X_{1}=0,393$. Persepsi Siswa tentang Metode Mengajar Guru memberikan sumbangan relatif sebesar 93,69\% dan sumbangan efektif sebesar $9,087 \%$.

Hasil penelitian ini didukung oleh pendapat Eveline Siregar dan Hartini Nara (2014:53-55) bahwa upaya guru dalam membelajarkan siswa berpengaruh dalam motivasi belajar siswa. Guru memiliki peran penting dan merupakan manajer yang berada di dalam kelas sehingga harus memiliki kemampuan mengelola dan memotivasi peserta didik khusunya dalam kegiatan belajar. Ukuran kinerja mengajar bagi guru perlu dirumuskan untuk dijadikan acuan dalam mengadakan perbandingan terhadap apa yang dicapai dengan apa yang diharapkan, sehingga tujuan yang dirumuskan dapat tercapai secara efektif dan efisien. Penggunaan metode mengajar yang menarik dan pemilihan media pembelajaran yang bervariasi akan memunculkan motivasi belajar siswa. Dalam hal ini, kinerja mengajar guru yang baik akan meningkatkan motivasi belajar siswa yang baik pula.

3. Pengaruh Kemandirian Belajar terhadap Motivasi Belajar Dasardasar Akuntansi

Berdasarkan hasil analisis regresi sederhana, diperoleh koefisien korelasi $r_{x 3 y}$ sebesar 0,765 yang bernilai positif berarti Kemandirian Belajar memilki pengaruh positif terhadap Motivasi Belajar Dasardasar Akuntansi. Harga koefisien determinasi $r_{x 2 y}^{2}$ sebesar 0,586 yang menunjukkan bahwa Kemandirian Belajar memiliki kontribusi pengaruh terhadap Motivasi Belajar Dasardasar Akuntansi Siswa Kelas X Akuntansi SMK Negeri 1 Tempel Tahun Ajaran 2018/2019 sebesar $58,6 \%$ sedangkan $41,4 \%$ ditentukan oleh variabel lain yang tidak diteliti dalam penelitian.

Hasil penelitian ini diperkuat dengan penelitian yang dilakukan oleh Sari Rumanti Palupi (2017) yang berjudul "Pengaruh Kemandirian Belajar, Persepsi Siswa tentang Metode Mengajar Guru dan Perhatian Orang Tua terhadap Prestasi Belajar Akuntansi Siswa Kelas XI IPS SMA Negeri 1 Srandakan Tahun Ajaran 2016/2017". Hasil penelitian menunjukkan bahwa terdapat pengaruh positif Kemandirian Belajar terhadap Prestasi Belajar Akuntansi Siswa Kelas XI IPS SMA Negeri 1 Srandakan Tahun Ajaran 2016/2017 
dibuktikan dengan $r_{x 1 y} 0,348$ dan $r^{2}{ }_{x 1 y}$ 0,121. Kemandiran Belajar memberikan sumbangan relatif sebesar $37,90 \%$ dan sumbangan efektif sebesar $5,99 \%$.

Kemandirian Belajar merupakan faktor yang dapat mempengarhi Motivasi Belajar Dasar-dasar Akuntansi yang muncul dari dalam diri siswa. Hasil penelitian ini didukung oleh pendapat Dimyati dan Mudjiono (2009) yang menyebutkan bahwa motivasi belajar dipengaruhi oleh beberapa faktor diantaranya kemauan dan kondisi siswa. Dalam hal ini kemandirian belajar dapat timbul apabila terdapat dua hal tersebut. Kemauan siswa berarti keinginan yang timbul dari dalam diri untuk melakukan kegiatan belajar dan kondisi siswa yang dimaksud adalah kondisi fisik dan psikis yang akan mempengaruhi tingkat motivasi ketika dia belajar. Upaya untuk meningkatkan Kemandirian Belajar siswa membutuhkan bantuan dari semua pihak termasuk guru dan orang tua. Peran guru dan orang tua dapat mendorong siswa untuk menyusun beberapa tujuan belajarnya sendiri dan kemudian memonitor kemajuan belajarnya. Dengan demikian siswa yang memiliki Kemandirian Belajar yang tinggi akan akan mempengaruhi Motivasi Belajar siswa tersebut.

4. Pengaruh Lingkungan Teman Sebaya, Kinerja Mengajar Guru, dan Kemandirian Belajar secara bersamasama terhadap Motivasi Belajar Dasar-dasar Akuntansi

Berdasarkan hasil analisis regresi ganda, diperoleh nilai koefisien korelasi $\mathrm{R}_{\mathrm{y}(123)}$ sebesar 0,786 yang bernilai positif berarti Lingkungan Teman Sebaya, Kinerja Mengajar Guru, dan Kemandirian Belajar secara bersama-sama memilki pengaruh positif terhadap Motivasi
Belajar Dasar-dasar Akuntansi. Nilai koefisien determinasi $\mathrm{R}_{\mathrm{y}(123)}^{2}$ sebesar 0,618 yang menunjukkan bahwa Lingkungan Teman Sebaya, Kinerja Mengajar Guru, dan Kemandirian Belajar secara bersama-sama memiliki kontribusi pengaruh terhadap Motivasi Belajar Dasardasar Akuntansi Siswa Kelas X Akuntansi SMK Negeri 1 Tempel Tahun Ajaran 2018/2019 sebesar $61,8 \%$ sedangkan $38,2 \%$ ditentukan oleh variabel lain yang tidak diteliti dalam penelitian.

Pengaruh ketiga variabel bebas diperkuat adanya sumbangan relatif dan sumbangan efektif dari ketiga variabel bebas. Lingkungan Teman Sebaya memberikan sumbangan relatif sebesar 15\%, Kinerja Mengajar Guru memberikan sumbangan relatif sebesar 14,2\%, dan Kemandirian Belajar memberikan sumbangan relatif sebesar $70,8 \%$. Sumbangan efektif yang diberikan oleh variabel Lingkungan Teman Sebaya sebesar 9,3\%, Kinerja Mengajar Guru memberikan sumbangan efektif sebesar 8,8\%, dan Kemandirian Belajar memberikan sumbangan efektif sebesar 43,7\%. Total sumbangan efektif sebesar $61,8 \%$ yang berarti Lingkungan Teman Sebaya, Kinerja Mengajar Guru, dan Kemandirian Belajar secara bersamasama memberikan sumbangan efektif sebesar 61,8\% terhadap Motivasi Belajar Dasar-dasar Akuntansi.

Hasil penelitian ini diperkuat oleh pendapat dari Hamalik (2004: 162) yang menyebutkan bahwa Motivasi Belajar dipengaruhi oleh faktor intrinsik dan ekstrinsik. Siregar dan Nara (2014:53-55) menjelaskan beberapa faktor tersebut yang dalam penelitian ini diantaranya adalah kondisi lingkungan siswa berupa 
Lingkungan teman Sebaya, upaya guru dalam membelajarkan peserta didik berupa Kinerja Mengajar Guru, kemauan dan kondisi siswa berupa Kemandirian Belajar. Apabila ketiga faktor tersebut memberikan dampak yang positif maka akan berpengaruh positif pula terhadap peningkatan Motivasi Belajar Dasar-dasar Akuntansi.

\section{SIMPULAN DAN SARAN}

\section{Simpulan}

a. Terdapat pengaruh positif Lingkungan Teman Sebaya terhadap Motivasi Belajar Dasardasar Akuntansi Siswa Kelas X Akuntansi SMK Negeri 1 Tempel Tahun Ajaran 2018/2019. Hal ini ditunjukkan dengan $r_{x 1 y}$ sebesar 0,$490 ; r^{2}$ xy sebesar 0,240 .

b. Terdapat pengaruh positif Kinerja Mengajar Guru terhadap Motivasi Belajar Dasar-dasar Akuntansi Siswa Kelas X Akuntansi SMK Negeri 1 Tempel Tahun Ajaran 2018/2019. Hal ini ditunjukkan dengan $r_{x 2 y}$ sebesar 0,$369 ; r^{2}{ }_{x 2 y}$ sebesar 0,136.

c. Terdapat pengaruh positif Kemandirian Belajar terhadap Motivasi Belajar Dasar-dasar Akuntansi Siswa Kelas X Akuntansi SMK Negeri 1 Tempel Tahun Ajaran 2018/2019. Hal ini ditunjukkan dengan $r_{x 3 y}$ sebesar 0,$765 ; r^{2} \times 3 y$.

d. Terdapat pengaruh positif Lingkungan Teman Sebaya, Kinerja Mengajar Guru, dan Kemandirian Belajar secara bersama-sama terhadap Motivasi Belajar Dasar-dasar Akuntansi Siswa Kelas X Akuntansi SMK Negeri 1 Tempel Tahun Ajaran 2018/2019. Hal ini ditunjukkan dengan $\mathrm{R}_{\mathrm{y}(123)}$ sebesar 0,786; $\mathrm{R}_{\mathrm{y}(123)}^{2}$ sebesar 0,618 .
Saran

a. Dukungan teman sebaya di rumah memiliki skor rendah, maka perlu ditingkatkan interaksi yang baik dan positif dengan lingkungan teman sebaya yang ada di rumah. Misalnya siswa dapat memanfaatkan waktu bermain dengan temannya sambil belajar, berlatih soal-soal, dan mengerjakan tugas secara kerja kelompok di rumah serta dapat saling membantu dalam hal kesulitan belajar.

b. Perlu upaya peningkatan kemandirian siswa dalam memanfaatkan waktu belajar di rumah yang salah satunya dengan mengulang materi yang telah dipelajari. Siswa harus membiasakan dirinya untuk membaca ulang materi yang telah disampaikan supaya tingkat pemahaman terhadap materi menjadi maksimal. Selain itu guru dapat meningkatkan kemandirian belajar siswa dengan cara memberikan tugas lain untuk mengulang materi yang telah dipelajari dan apabila ada materi yang kurang dipahami bisa untuk ditanyakan saat pertemuan yang akan datang.

c. Guru diharapkan sesekali dapat memberikan reward atau pujian kepada siswa yang sudah aktif dalam kegiatan pembelajaran. Pemberian reward dapat berupa tambahan nilai keaktifan atau pemberian pujian dalam bentuk lain sehingga siswa menjadi termotivasi untuk aktif dalam belajar.

d. Diharapkan dalam penelitian selanjutnya dapat diteliti lebih lanjut mengenai faktor-faktor lain yang dapat mempengaruhi Motivasi Belajar seperti Pemanfaatan Sumber Belajar, Media Pembelajaran, Fasilitas Sekolah, dan lain sebagainya. 


\section{DAFTAR PUSTAKA}

Depdikbud. (2003). UU Nomor 20 Tahun 2003, tentang Sistem Pendidikan Nasional.

Dimyati \& Mudjiono. (2009) Belajar \& Pembelajaran. Jakarta: PT Rineka Cipta.

Hamalik, Oemar. (2004). Proses Belajar Mengajar. Jakarta: Bumi Aksara.

Kumalasari, Anggun Palupi. (2016). "Pengaruh Pemanfaatan Sumber Belajar dan Persepsi Siswa tentang Metode Mengajar Guru terhadap Motivasi Belajar Akuntansi Siswa Kelas XI Akuntansi SMK Negeri 1 Tempel Tahun Ajaran 2015/2016". Skripsi. Yogyakarta: FE UNY.

Lestari, Puji. (2017). "Pengaruh Aspirasi Siswa, Lingkungan Teman Sebaya, dan Pemanfaatan Sumber Belajar terhadap Motivasi Belajar Akuntansi Perusahaan Jasa Siswa Kelas X Akuntansi SMK Negeri 2 Purworejo Tahun Ajaran 2016/2017”. Skripsi. Yogyakarta: FE UNY.

Mukti, Titis Haryo. (2016). "Pengaruh Persepsi Siswa tentang Metode Mengajar Guru dan Media Pembelajaran terhadap Motivasi Belajar pada Kompetensi Kejuruan Akutansi Kelas XI SMK YPKK 1 Sleman Tahun Ajaran 2015/2016". Skripsi. Yogyakarta: FE UNY.

Palupi, Sari Rumanti. (2017). "Pengaruh Kemandirian Belajar, Persepsi Siswa tentang Metode Mengajar Guru dan Perhatian Orang Tua terhadap Prestasi Belajar Akuntansi Siswa Kelas XI IPS SMA Negeri 1 Srandakan Tahun Ajaran 2016/2017'. Skripsi. Yogyakarta: FE UNY.
Peraturan Pemerintah No 17 Tahun 2010 tentang Pengelolaan dan Penyelenggaraan Pendidikan.

Rusman. (2014). Model-model Pembelajaran: Mengembangkan Profesionalisme Guru. Jakarta: PT Rajagrafindo Persada.

Santrock, John W. (2009). Psikologi Pendidikan, Edisi 3, Buku 1. Jakarta: Salemba Humanika.

Sardiman. (2014). Interaksi \& Motivasi Belajar Mengajar. Jakarta: PT Raja Grafindo Persada.

Siregar, Eveline \& Hartini Nara. (2014). Teori Belajar dan Pembelajaran. Bogor: Ghalia Indonesia.

Sugihartono, dkk. (2013). Psikologi Pendidikan. Yogyakarta: UNY Press.

Sugiyono. (2015). Metode Penelitian Kuantitatif, Kualitatif, dan $R \& D$. Bandung: Alfabeta. . (2015). Statistika untuk Penelitian. Bandung: Alfabeta.

Tirtarahardja, Umar \& S.L. La Sulo. (2005). Pengantar Pendidikan. Jakarta: PT Rineka Cipta.

www.smkn1tempel.sch.id/akuntansi-dankeuangan-lembaga (diakses pada 21 Januari 2019)

Yamin, Martinis. (2008). Desain Pembelajaran Berbasis Tingkat Satuan Pendidikan. Jakarta: Gaung Persada Press. 